\title{
Kekeliruan Pemahaman Tentang Online Grooming dalam Sistem Hukum di Indonesia
}

\author{
Annisa Hafizhah*, Lamsumihar Andjelina Panggabean \\ Fakultas Hukum, Universitas Sumatera Utara \\ ${ }^{\star}$ Penulis Koresponden: Kaknisa1302@gmail.com
}

\section{ABSTRAK}

Hukum diciptakan manusia untuk melindungi dan menertibkan masyarakat. Sayangnya, hukum yang dibuat manusia memiliki keterbatasan saat berhadapan dengan perubahan zaman. Pola kehidupan masyarakat terus berkembang dan hukum dituntut untuk selalu bisa menyeleraskan diri padahal proses menciptakan hukum tidak mudah. Perlu pemikiran dan waktu yang cukup untuk merumuskan peraturan yang baik sementara masyarakat tidak bisa menunggu hukum terlalu lama untuk menyelesaikan berbagai fenomena yang terjadi, termasuk online grooming. Online grooming adalah kekerasan berbasis gender yang dilakukan secara online untuk memperdaya korban agar menyerahkan foto atau video yang memuat atribut seksualnya. Saat ini belum ada peraturan yang secara khusus mengatur online grooming, namun ada beberapa metode tertentu yang bisa digunakan agar peraturan perundangundangan yang ada saat ini bisa dipakai untuk menjerat pelaku online grooming.

Kata Kunci: Kepastian hukum; Online grooming; Peraturan perundang-undangan

\section{ABSTRACT}

Law was created by humans to protect and order society. Unfortunately, human-made laws have limitations when facing the massive development. The pattern of people's culture continues to develop and the law is expected to always be relevant even though the process of creating laws is not easy. It takes a lot of concern and time to formulate good rules, while society cannot wait too long for the law to resolve various phenomena that occur, including online grooming. Online grooming is an online gender-based violence that is carried out to trick victims into submitting photos or videos that contain their sexual attributes. Currently there are no regulations that specifically regulate online grooming, but there are certain methods that can be used so that the existing laws and regulations can be used to arrest online grooming criminals.

Kata Kunci: Legal certainty, Online grooming, Statutory regulations

\section{PENDAHULUAN}

Hukum adalah himpunan peraturan yang berisi perintah dan larangan untuk menertibkan masyarakat sehingga ia harus ditaati (Rahardjo, 2005:38) Menyatakan diri sebagai negara hukum, ${ }^{1}$ Indonesia harus mampu menjamin kehidupan masyarakat dan melindungi setiap warganya ${ }^{2}$ melalui ketersediaan hukum (kepastian hukum).

Kepastian hukum merujuk pada pemberlakuan hukum yang jelas, tetap, dan konsisten dimana pelaksanaannya tidak dapat dipengaruhi oleh keadaan-keadaan yang sifatnya subjektif (Ismail, 2011:2). Kepastian hukum diartikan sebagai kejelasan norma sehingga dapat dijadikan pedoman bagi masyarakat yang dikenakan peraturan ini. Pengertian kepastian tersebut dapat dimaknai

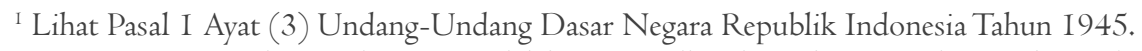

${ }^{2}$ Tujuan negara modern pada intinya adalah mewujudkan kesejahteraan rakyat. Lihat Ni’Matul Huda, Ilmu Negara (Jakarta: Rajawali Press, 2013), 2.
} 
bahwa ada kejelasan dan ketegasan terhadap berlakunya hukum di dalam masyarakat agar tidak menimbulkan banyak salah tafsir (Prayogo, 2016:194).

Hukum diciptakan manusia untuk menunjukkan bagaimana masyarakat seharusnya bersikap (hukum sebagai pedoman perilaku) (Goesnadhie, 2010:199). Persepsi masyarakat yang menjadikan hukum sebagai pedoman perilaku menuntut peraturan perundang-undangan harus mampu menguraikan secara jelas dan eksplisit tentang perbuatan apa yang boleh dilakukan masyarakat dan perbuatan apa yang dilarang.

Masyarakat awam umumnya memandang hukum hanya sebatas peraturan perundang-undangan yang berlaku saja (hukum positif ${ }^{3}$ ) padahal sebenarnya hukum jauh lebih luas dan kompleks dari sekedar kumpulan peraturan semata. Perkembangan zaman yang sangat cepat memang menyulitkan hukum untuk memenuhi kebutuhan hukum yang timbul karenanya, termasuk munculnya berbagai kekerasan dan kejahatan baru yang semakin variatif (Situngkir, 2018:3).

Salah satu contoh kejahatan baru yang muncul karena perkembangan kehidupan masyarakat yang dinamis adalah online grooming. Online grooming merupakan salah satu bentuk kekerasan berbasis gender online yang menggunakan kemajuan teknologi dan informasi dalam pelaksanaannya.

Kekerasan berbasis gender online (selanjutnya disingkat KBGO) adalah tindak kekerasan yang memiliki niatan untuk melecehkan korban berdasarkan gender yang dilakukan dengan memanfaatkan teknologi (SAFENet, 2021). Ada 9 bentuk KBGO yang dilaporkan kepada Komisi Nasional Perempuan dan online grooming adalah salah satu diantaranya yang menempati nomor urut dua sebagai kekerasan yang paling banyak dilaporkan dengan jumlah laporan sebanyak 307 kasus (Komnas Perempuan, 2021).

Online grooming adalah sikap pelaku untuk mendekati korban dan membangun koneksi emosional dengan seseorang di dunia maya hingga memperoleh kepercayaan korban (Komnas Perempuan, 2021). Pelaku kemudian akan meyakinkan korban untuk segera mengirimkan foto/video yang memuat atribut seksual korban baik sebagian maupun telanjang kepada pelaku.

Sampai saat ini, memang belum ada peraturan perundang-undangan yang secara khusus mengatur mengenai online grooming sehingga masyarakat awam beranggapan bahwa tidak akan ada pasal dalam peraturan perundang-undangan (hukum positif) Indonesia yang dapat digunakan untuk menjerat pelaku online grooming.

Hukum membutuhkan proses yang panjang untuk membentuk suatu peraturan perundangundangan ${ }^{4}$ yang baik untuk menjalankan fungsinya dalam mengatur kehidupan bersama manusia. Tetapi, hukum juga memiliki metode-metode tersendiri untuk mengatasi kondisi tertentu saat kejahatan berkembang pesat dan hukum kesulitan mengimbangi perkembangan zaman.

Hukum tidak mungkin membiarkan pelaku online grooming bebas berkeliaran begitu saja sebab hal tersebut akan merusak esensi dan tujuan dari hukum itu sendiri yakni keadilan, kepastian, dan

\footnotetext{
3 Hukum positif (ius constitutum) adalah hukum yang dinyatakan berlaku di suatu wilayah pada ruang lingkup waktu dan ruang lingkup tempat tertentu. Lihat Sudikno Mertokusumo, Mengenal Hukum: Suatu Pengantar, (Yogyakarta: Liberty, 2007), I27-I28.

4 Pelajari lebih lanjut dalam Undang-Undang Republik Indonesia Nomor 12 Tahun 201 I Tentang Pembentukan Peraturan Perundang-Undangan dan Undang-Undang Republik Indonesia Nomor I5 Tahun 2019 Tentang Perubahan Atas UndangUndang Nomor 12 Tahun 201 I Tentang Pembentukan Peraturan Perundang-Undangan.
} 
kemanfaatan bagi masyarakat. Hakim sebagai penegak hukum bisa menggunakan metode penafsiran hukum, konstruksi hukum, dan penemuan hukum untuk menyelesaikan suatu perkara yang belum memiliki pengaturan yang jelas dalam hukum positif saat ini. Penafsiran hukum dilakukan untuk menemukan hukum. Penafsiran hukum merupakan proses mencari dasar hukum yang tepat untuk mengadili suatu perkara yang belum jelas ketentuan hukum yang mengaturnya (Christianto, 2011:479).

Fungsi dari penafsiran pada dasarnya adalah untuk: 1) Memahami makna asas atau kaidah hukum; 2) Menghubungkan suatu fakta hukum dengan kaidah hukum; 3) Menjamin penerapan atau penegakan hukum dapat dilakukan secara tepat, benar, dan adil; dan 4) Mempertemukan antara kaidah hukum dengan perubahan-perubahan sosial agar kaidah hukum tetap aktual mampu memenuhi kebutuhan sesuai dengan perubahan masyarakat (Manan, 2009:5).

Konstruksi hukum dapat digunakan hakim sebagai metode penemuan hukum apabila dalam mengadili perkara tidak ada peraturan yang mengatur secara khusus mengenai peristiwa yang terjadi. Konstruksi hukum dapat dilakukan menggunakan logika berpikir secara analogi dan penyempitan hukum (Hukum Online, 2017).

Rechtvinding atau penemuan hukum adalah proses pembentukan hukum oleh hakim/aparat penegak hukum lainnya dalam penerapan peraturan umum terhadap peristiwa hukum yang konkrit dan hasil penemuan hukum menjadi dasar untuk mengambil keputusan (FH Universitas Tanjungpura, 2020).

Keberadaan berbagai metode inilah yang akan menjadi jembatan penghubung antara perbuatan baru yang belum diatur dengan berbagai peraturan perundang-undangan yang sudah ada sehingga tidak ada pelaku yang bisa lolos dari hukum dengan alasan ketiadaan hukum yang mengatur, termasuk juga pelaku online grooming.

Berdasarkan latar belakang tersebut, dapat diidentifikasi beberapa masalah yang dapat dicermati dalam pembahasan mengenai kekeliruan pemahaman tentang online grooming dalam sistem hukum di Indonesia yaitu bagaimana cara memahami hukum di Indonesia dan bagaimana keberadaan online grooming dalam sistem hukum di Indonesia).

\section{METODE PENELITIAN}

Penelitian ini merupakan penelitian hukum normatif ${ }^{5}$ yang menjadikan online grooming sebagai objek penelitiannya. Menggunakan pendekatan konseptual dan pendekatan perundang-undangan, pendekatan konseptual digunakan untuk mendefinisikan online grooming sementara pendekatan perundang-undangan digunakan untuk menganalisa pengaturan online grooming dalam sistem hukum Indonesia.

Penelitian hukum normatif (yuridis normatif) adalah penelitian yang bertujuan untuk meneliti asasasas hukum, sistematika hukum, sinkronisasi hukum, sejarah hukum, teori hukum, dan perbandingan hukum (Soekanto, 2007) dengan melihat norma-norma hukum yang terdapat di dalam peraturan perundang-undangan yang berlaku (Amirudin dan Asikin, 1994).

\footnotetext{
${ }^{5}$ Penelitian hukum normatif adalah suatu proses untuk menemukan suatu aturan hukum, prinsip-prinsip hukum maupun doktrin-doktrin hukum guna menjawab isu hukum yang dihadapi. Lihat Peter Mahmud Marzuki, Penelitian Hukum (Jakarta: Kencana Prenada Media, 2010), 35.
} 
Menggunakan sumber data sekunder, bahan hukum yang digunakan dalam penelitian ini adalah:

1. Bahan Hukum Primer yakni peraturan perundang-undangan meliputi:

a. Undang-Undang Dasar Negara Republik Indonesia Tahun 1945;

b. Undang-Undang Republik Indonesia Nomor 44 Tahun 2008 tentang Pornografi.

c. Undang-Undang Republik Indonesia Nomor 48 Tahun 2009 tentang Kekuasaan Kehakiman.Undang-Undang Republik Indonesia Nomor 12 Tahun 2011 Tentang Pembentukan Peraturan Perundang-Undangan dan Undang-Undang Republik Indonesia Nomor 15 Tahun 2019 Tentang Perubahan Atas Undang-Undang Nomor 12 Tahun 2011 Tentang Pembentukan Peraturan Perundang-Undangan.

d. Undang-Undang Republik Indonesia Nomor 35 Tahun 2014 tentang Perlindungan Anak.

e. Undang-Undang Republik Indonesia Nomor 19 Tahun 2016 tentang Perubahan Atas Undang-Undang Nomor 11 Tahun 2008 tentang Informasi dan Transaksi Elektronik.

2. Bahan Hukum Sekunder, meliputi: literatur-literatur yang terkait dengan permasalahan yang dikaji yang berasal dari buku-buku, pendapat ahli hukum dari segi kepustakaan, jurnal, dan artikel internet.

3. Bahan hukum tersier atau penunjang, baik yang dibidang hukum maupun diluar bidang hukum yang digunakan untuk melengkapi data penulisan artikel ini.

Teknik yang digunakan di dalam pengumpulan data adalah library research atau studi kepustakaan. Bahan kepustakaan diperoleh dari berbagai sumber yang validitasnya dapat di pertanggungjawabkan berupa jurnal ilmiah, buku, dan artikel di media massa yang diperoleh secara cetak maupun online. Pengumpulan data melalui media internet dilakukan dengan memilih sumber website yang dapat dipertanggungjawabkan, seperti situs departemen resmi negara maupun media massa online.

Seluruh bahan hukum yang berhasil dikumpulkan, selanjutnya diinventarisasi, diklasifikasi, dan dianalisis dengan menggunakan analisis deskriptif yang bertujuan untuk menguraikan berbagai permasalahan hukum yang ada. Penulisan artikel ini bersifat deskriptif analitis, yaitu suatu metode yang digunakan untuk mempelajari permasalahan yang ada dalam masyarakat, serta tata cara yang berlaku dalam masyarakat sehari-hari serta situasi-situasi tertentu (Nazir, 20015:35)

Tujuan dari penulisan deskriptif ini adalah untuk membuat gambaran atau lukisan secara sistematis, faktual dan akurat mengenai fakta-fakta, sifat-sifat, serta hubungan yang antar fenomena yang teliti untuk mendapatkan suatu pemecahan. Setelah proses analisis, dilakukan proses sintesis dengan menarik dan menghubungkan rumusan masalah, tujuan penulisan serta pembahasan yang dilakukan. Berikutnya ditarik simpulan yang bersifat umum kemudian direkomendasikan beberapa hal sebagai upaya transfer gagasan.

\section{HASIL DAN PEMBAHASAN}

\section{Kekeliruan Pemahaman tentang Sistem Hukum di Indonesia}

Radbruch menuliskan bahwa di dalam hukum terdapat 3 (tiga) nilai dasar, yakni: (1) Keadilan (Gerechtigkeit); (2) Kemanfaatan (Zweckmassigkeit); dan (3) Kepastian Hukum (Rechtssicherheit). Kepastian hukum dimaknai sebagai suatu keadaan dimana telah pastinya hukum karena adanya kekuatan yang mengikat bagi hukum yang bersangkutan (Rahardjo, 2005:19). 
Keberadaan asas kepastian hukum merupakan sebuah bentuk perlindungan bagi yustisiabel (pencari keadilan) dari tindakan sewenang-wenang yang mungkin dilakukan penguasa (Mertokusumo, 1993:2). Masyarakat tidak akan dihukum tanpa suatu alasan yang jelas, sebab sebelumnya telah ada suatu peraturan tertulis yang menjelaskan perbuata apa yang dilarang dan apa konsekuensi yang akan diberikan jika larangan tersebut dilanggar.

Perlu disadari bahwa aturan hukum buatan manusia pasti memiliki kelemahan. Akal manusia tidak bisa memprediksi pola perilaku manusia beserta fenomena yang akan terjadi di masa yang akan datang. Perkembangan zaman begitu cepat dan dinamis sementara kemampuan akal pikiran manusia terbatas sehingga ada kalanya hukum tidak akan mampu merespon persitiwa baru yang muncul akibat perkembangan zaman tersebut. Kondisi inilah yang kemudian disebut dengan kekosongan hukum dan ketidakpastian hukum.

Kekosongan hukum dan ketidakpastian hukum terjadi ketika suatu peristiwa tidak memiliki peraturan perundangan-perundangan yang mengaturnya dengan jelas, peraturannya ada tapi tumpang tindih, atau bahkan peraturannya memang sama sekali tidak ada.

Ketika terjadi kekosongan hukum, masyarakat umumnya memandang hal tersebut sebagai suatu kegagalan fatal dan dengan segera akan menuntut negara untuk mengeluarkan peraturan baru yang khusus mengatur perbuatan baru yang belum diatur tersebut. Padahal, sebenarnya ada metode tertentu yang bisa digunakan hakim sebagai penegak hukum untuk mengisi kekosongan hukum tersebut melalui metode penafsiran hukum, konstruksi hukum, ataupun penemuan hukum.

Penafsiran hukum (legal interpretation) diperlukan dalam penerapan hukum tertulis untuk menemukan dan membentuk hukum. Penemuan hukum merupakan kegiatan untuk memperjelas ketentuan-ketentuan hukum tertulis yang sudah ada, yang dapat diberlakukan bagi suatu aspek kehidupan tertentu. Pembentukan hukum tersebut bertujuan untuk membentuk, menyusun atau membangun hukum bagi aspek kehidupan tertentu yang belum ada hukumnya.

Penafsiran hukum hendaknya diikuti dengan penalaran hukum (legal reasoning), yaitu upaya yang dilakukan untuk memberi alasan dan penjelasan hukum agar hasil penafsiran hukum masuk akal dan dapat dipahami secara logika. Hasil penafsiran dan penalaran hukum tersebut harus disampaikan dengan menggunakan argumentasi hukum yang rasional agar kepastian hukum, keadilan, dan kebenaran dapat ditegakkan.

Penemuan hukum merupakan tugas mutlak bagi hakim sebab pengadilan dilarang menolak untuk memeriksa, mengadili, dan memutus suatu perkara yang diajukan dengan alasan bahwa hukum tidak ada atau kurang jelas, melainkan wajib untuk memeriksa dan mengadilinya dengan menggali, mengikuti dan memahami nilai-nilai hukum yang hidup dalam masyarakat demi upaya penemuan hukum. ${ }^{6}$

Hal ini juga berlaku untuk online grooming, meskipun belum ada ketentuan hukum yang mengatur secara spesifik mengenai online grooming, online grooming tetap dapat diproses secara hukum dengan menggunakan metode penemuan hukum yang merupakan tugas dari hakim.

Hakim dapat menganalisa dan mencari hukum apa yang cocok untuk menjerat pelaku online grooming melalui berbagai peraturan perundang-undangan yang saat ini berlaku di Indonesia.

${ }^{6}$ Lihat Pasal 10 Ayat (I) dan Pasal 5 Ayat (I) Undang-Undang Republik Indonesia Nomor 48 Tahun 2009 tentang Kekuasaan Kehakiman 
Melalui metode penemuan hukum maka tidak akan terjadi kekosongan hukum dalam mengatur dan menjerat pelaku online grooming sehingga tujuan hukum untuk memenuhi keadilan, kepastian, dan kemanfaatan akan senantiasa dapat terjaga.

Merupakan sebuah kekeliruan apabila masyarakat berpikir bahwa sama sekali tidak ada aturan hukum dalam hukum positif Indonesia saat ini yang dapat menjerat pelaku online grooming karena pada dasarnya sistem hukum Indonesia telah memberikan mekanisme untuk mengatasi hal tersebut.

Hukum tidak dapat hanya dimaknai sebatas apa yang tertulis secara nyata dalam suatu pasal peraturan perundang-undangan. Hukum adalah suatu kesatuan sistem kompleks yang terdiri dari berbagai peraturan perundang-undangan dan metode-metode tertentu yang khusus diberikan bagi penegak hukum yang digunakan untuk memenuhi kebutuhan hukum masyarakat.

Hakim tidak boleh menolak suatu perkara yang datang kepadanya di pengadilan dengan alasan peraturan yang mengaturnya tidak memadai, entah karena hukum yang tidak jelas, tidak ada, atau ada tetapi tumpang tindih. Justru hakim benar-benar harus menggali dan menyelesaikan setiap perkara yang datang kepadanya dengan memanfaatkan keilmuan yang dimilikinya.

Memang hakim harus mengutamakan hukum tertulis (aneka peraturan perundang-undangan) dalam menyelesaikan perkara sebagai pedoman yang telah dibuat oleh lembaga yang berwenang. Namun, hakim tidak semestinya hanya terpatok pada keberadaan peraturan tertulis saja. Hakim bukan corong undang-undang yang sekedar membacakan peraturan tertulis untuk menghukum masyarakat. Hakim adalah penegak hukum yang wajib menjaga kehormatan hukum untuk melindungi dan menertibkan masyarakat, sesuai dengan tujuan hukum itu sendiri yakni untuk keadilan, kepastian, dan kemanfaatan.

\section{Keberadaan Online grooming dalam Sistem Hukum di Indonesia}

Online grooming merupakan salah satu bentuk kejahatan berbasis gender yang dilakukan secara online sebagai dampak dari kemajuan teknologi dan informasi serta penggunaan media sosial yang semakin luas. Secara sederhana, online grooming merupakan pendekatan untuk menjalin kedekatan emosional melalui media teknologi untuk mencari calon korban yang memiliki potensi baik secara usia, kondisi, tubuh, maupun ekonomi untuk dilecehkan atau ditipu.

Pelaku online grooming memanfaatkan media sosial sebagai sarana untuk menjerat target dan korban yang rentan. Online grooming atau pendekatan untuk memperdaya ini dapat menimpa seluruh lapisan masyarakat, perempuan ataupun laki-laki, anak-anak maupun orang dewasa. Namun, perempuan dan anak-anak adalah golongan yang paling rentan karena faktor gender maupun usianya.

Sampai saat ini, Indonesia memang belum memiliki peraturan perundang-undangan yang secara khusus mengatur mengenai kekerasan berbasis gender online termasuk online grooming. Hal inilah yang kemudian menyebabkan masyarakat khususnya korban enggan melaporkan kasus online grooming yang menimpanya kepada pihak yang berwajib.

Masyarakat beranggapan bahwa dengan tidak adanya peraturan perundang-undangan yang secara khusus dan eksplisit mengatur online grooming, maka tidak akan aturan hukum yang mampu menangani online grooming dan menjerat pelaku. Padahal, apabila ditelusuri lebih lanjut, peraturan perundang-undangan yang ada saat ini cukup mampu menjerat pelaku online grooming meskipun memang masih tersebar ke dalam beberapa peraturan perundang-undangan yang berbeda. 
Salah satu kasus online grooming yang dapat dijadikan contoh adalah kasus TR (25 tahun) yang merupakan seorang narapidana di Jawa Timur. TR ditangkap pada 9 Juli 2019 karena melakukan pencabulan terhadap anak-anak di bawah umur melalui media sosial. Polisi kemudian berhasil mengidentifikasi setidaknya 50 anak yang menjadi korban dalam konten tersebut. TR dikenakan pasal 82 dan 76E Undang-Undang Nomor 35 Tahun 2014 tentang Perlindungan Anak, Pasal 29 jo Pasal 4 ayat (1) jo Pasal 37 Undang-Undang Nomor 44 Tahun 2008 tentang Pornografi serta Pasal 45 ayat (1) jo Pasal 27 ayat (1) Undang-Undang Nomor 19 Tahun 2016 tentang ITE (Kompas, 2019).

Kasus TR menunjukkan bahwa walaupun tanpa peraturan perundang-undangan yang secara khusus mengatur online grooming, pelaku online grooming tetap dapat dikenakan hukum. Melalui metode-metode yang boleh digunakan hakim dalam proses mengadili, pelaku online grooming dapat diberi sanksi dengan memanfaatkan ketentuan peraturan perundang-undangan yang telah ada.

\section{Online Grooming dalam Undang-Undang Perlindungan Anak}

Undang-undang perlindungan anak hanya dapat digunakan apabila korban dari kasus online grooming adalah anak-anak. Adapun pasal-pasal yang dapat digunakan untuk menjerat pelaku online grooming dalam undang-undang ini adalah Pasal 76E, Pasal 76I, Pasal 82 dan Pasal 88. ${ }^{7}$

Pasal 76E mengatur larangan perbuatan cabul pada anak yang dilakukan dengan kekerasan maupun ancaman kekerasan melalui pemaksaan, bujuk rayu, tipu muslihat ataupun rangkaian kata bohong. Pelaku akan diancam dengan sanksi penjara maksimal 15 tahun disertai denda maksimal 5 miliar rupiah sebagaimana yang tertera pada Pasal 82.

Pasal pencabulan anak ini memiliki kemiripan dengan perbuatan online grooming walaupun memang tidak menyebutkan penggunaan media online dalam pelaksanaannya. Begitupun dengan definisi perbuatan cabul yang masih menjadi perdebatan, apakah proses pengiriman foto/video yang memuat atribut seksual seseorang secara online bisa dikategorikan sebagai pencabulan yang dimaksud pada pasal tersebut.

\section{Online grooming dalam Undang-Undang Pornografi}

Gabungan pasal-pasal dalam Undang-Undang Nomor 44 Tahun 2008 tentang Pornografi yang dapat digunakan untuk menjerat pelaku online grooming adalah Pasal 4, Pasal 27, Pasal 29, dan Pasal $37 .^{8}$

Pasal 4 melarang semua orang untuk memproduksi, membuat, menyebar, atau mengimpor konten pornografi yang secara jelas memuat persenggamaan (hubungan badan antara suami dan istri), kekerasan seksual, ketelanjangan atau tampilan yang mengesankan ketelanjangan dan alat kelamin.

Jika perbuatan pada Pasal 4 tersebut dilakukan secara online dengan menggunakan data elektronik ${ }^{9}$, maka data tersebut dilampirkan sebagai bukti untuk kemudian dapat dimusnahkan atau dihapus. Setiap pejabat yang terlibat pada semua tingkat pemeriksaan untuk menangani suatu perkara wajib

\footnotetext{
7 Lihat Pasal-Pasal tersebut dalam Undang-Undang Republik Indonesia Nomor 35 Tahun 2014 tentang Perlindungan Anak

${ }^{8}$ Lihat lebih lanjut dalam Undang-Undang Nomor 44 Tahun 2008 tentang Pornografi

${ }^{9}$ Foto dan video termasuk dalam kategori data elektronik. Lihat Pasal I Angka I Undang-Undang Republik Indonesia Nomor I9 Tahun 2016 tentang Perubahan Atas Undang-Undang Nomor II Tahun 2008 tentang Informasi dan Transaksi Elektronik.
} 
merahasiakan isi ataupun informasi yang terdapat dalam data elektronik tersebut sebagaimana yang diatur dalam Pasal 27.

Pelaku dapat diancam dengan sanksi penjara maksimal 12 tahun dengan denda maksimal 6 miliar rupiah sebagaimana yang tertera pada Pasal 29. Namun, apabila pelaku melakukan perbuatan terebut pada anak-anak, maka batas maksimal hukumannya bisa ditambah sepertiga sehingga batas maksimal penjaranya berubah menjadi 16 tahun dengan denda maksimal 8 miliar sebagaimana yang diperintahkan Pasal 37.

\section{Online grooming dalam Undang-Undang Informasi dan Transaksi Elektronik}

Undang-Undang Informasi dan Elektronik Nomor 19 Tahun 2016 telah merubah beberapa ketentuan yang terdapat dalam Undang-Undang Nomor 11 Tahun 2008. Perubahan ini tidak serta merta menjadikan berbagai ketentuan yang terdapat dalam undang-undang nomor 11 tahun 2008 menjadi tidak berlaku.

Rumusan pasal pada undang-undang nomor 11 tahun 2008 tetap berlaku asalkan undang-undang nomor 19 tahun 2016 tidak merubahnya. Kalau undang-undang yang baru merubah bunyi suatu pasal dalam undang-undang yang lama, maka yang dipakai untuk menangani suatu masalah hukum adalah bunyi pasal yang terdapat dalam undang-undang terbaru.

Pasal 27 ayat (1) Undang-Undang Informasi dan Transaksi Elektronik mengatur larangan bagi setiap orang untuk mendistribusikan, mentransmisikan, atau membuat dapat diaksesnya suatu data elektronik yang isinya memuat pelanggaran kesusilaan. Pelaku akan diancam dengan sanksi penjara maksimal 6 tahun disertai denda maksimal 1 miliar rupiah sebagaimana yang tertera pada Pasal $45 .{ }^{10}$

Berbagai pasal yang terdapat dalam beberapa peraturan perundang-undangan ini memang tidak sempurna mengatur larangan perbuatan online grooming sebagaimana mestinya. Namun, memanfaatkan hukum yang telah ada ini masih lebih baik daripada harus menunggu berlakunya ketentuan hukum baru yang mengatur online grooming dan kekerasan berbasis gender online lainnya.

Aneka peraturan perundang-undangan tertulis tidak semestinya harus selalu dipandang terpisah antara satu dengan yang lain. Penomoran peraturan perundang-undangan yang berbeda tidak menghalangi penggunaan aneka pasal dalam beberapa undang-undang sekaligus.

Penegak hukum bisa memanfaatkan beberapa pasal sekaligus untuk menghukum pelaku atas suatu perbuatan yang dilakukannya jika memang dibutuhkan demikian dengan menggunakan kata juncto (biasa disingkat jo) yang menghubungkan antara satu pasal dengan pasal lain. Jika menemukan kata jo pada sederet pasal dari peraturan yang berbeda dalam menangani suatu perkara, berarti keseluruhan deret pasal itulah yang akan digunakan untuk meminta pertanggungjawaban pelaku.

Kembali pada contoh kasus di atas, TR dikenakan pasal 82 dan 76E Undang-Undang Nomor 35 Tahun 2014 tentang Perlindungan Anak, Pasal 29 jo Pasal 4 ayat (1) jo Pasal 37 Undang-Undang Nomor 44 Tahun 2008 tentang Pornografi serta Pasal 45 ayat (1) jo Pasal 27 ayat (1) UndangUndang Nomor 19 Tahun 2016 tentang ITE.

\footnotetext{
${ }^{10}$ Baca lebih lanjut Undang-Undang Republik Indonesia Nomor I9 Tahun 2016 tentang Perubahan Atas Undang-Undang Nomor II Tahun 2008 tentang Informasi dan Transaksi Elektronik.
} 
Atas perbuatan TR yang melakukan online grooming, TR dikenakan 3 undang-undang sekaligus: UU Perlindungan Anak, UU Pornografi, dan UU ITE. Ketiga undang-undang ini dipakai bersamaan oleh penegak hukum untuk mengakomodir ketiadaan peraturan tersendiri tentang KBGO secara umum ataupun online grooming secara khusus.

Meskipun menggunakan 3 undang-undang dengan berbagai pasal yang memberikan hukuman berbeda-beda, hal tersebut tidak berarti bahwa aneka hukuman tersebut akan dijumlahkan dan dibebankan sekaligus pada pelaku. Ada teknik dan metode tertentu lagi dalam hukum untuk menghitung dan menentukan hukuman apa yang paling tepat diberikan pada pelaku yang perbuatannya tercantum dalam berbagai peraturan sekaligus seperti yang dialami TR.

Suatu perbuatan tidak harus selalu diakomodir secara khusus dan eksplisit pada satu pasal di satu peraturan perundang-undangan saja. Pun, sebaliknya, suatu pasal pada peraturan perundangundangan tidak harus selalu hanya mengatur satu perbuatan tertentu saja. Terdapat berbagai teknik dalam penyusunan peraturan perundang-undangan dan tim penyusun peraturan perundangundangan mestinya telah memperhitungkan dengan cermat antara kebutuhan hukum masyarakat, perkembangan zaman yang pesat, dan keberlanjutan peraturan hukum itu sendiri di masa mendatang agar relevansi hukumnya bisa bertahan cukup lama.

\section{KESIMPULAN}

Ketiadaan frasa online grooming dalam peraturan perundang-undangan di Indonesia tidak berarti bahwa perbuatan tersebut sama sekali tidak diatur. Hukum memiliki cara-cara tertentu dalam menerapkan peraturan perundang-undangan melalui metode penafsiran hukum, konstruksi hukum, ataupun penemuan hukum.

Mahkamah Agung sebagai lembaga pengadilan yang berwenang untuk memberi petunjuk pada lingkungan peradilan lainnya hendaknya mengeluarkan suatu peraturan yang mengatur penyelesaian online grooming di hadapan hukum sembari menunggu Presiden dan Dewan Pertimbangan Rakyat selaku pembentuk hukum di Indonesia untuk membuat peraturan perundang-undangan yang lebih khusus mengatur tentang kekerasan berbasis gender, baik yang dilakukan secara online ataupun konvensional.

\section{DAFTAR PUSTAKA}

Buku

Amirudin \& Asikin, Z. 1994. Pengantar Metode Penelitian Hukum. Jakarta: PT. Raja Grafindo Persada.

Huda, Ni'Matul. 2013. Ilmu Negara. Jakarta: Rajawali Press.

Marzuki, Peter Mahmud. 2010. Penelitian Hukum. Jakarta: Kencana Prenada Media.

Mertokusumo, Sudikno. 1993. Bab-Bab Tentang Penemuan Hukum. Bandung: Citra Aditya Bakti.

Mertokusumo, Sudikno. 2007. Mengenal Hukum: Suatu Pengantar. Yogyakarta: Liberty.

Nazir, Moh. 2005. Metode Penelitian. Jakarta: Ghalia Indonesia.

Raharjo, Satjipto. 2005. Ilmu Hukum. Bandung: Citra Aditya Bakti.

Soekanto, S. 2007. Pengantar Penelitian Hukum. Jakrta: UI Press. 
Jurnal

Christianto, Hwian. 2011. "Penafsiran Hukum Progresif dalam Perkara Pidana," Mimbar Hukum. vol. 23 , no. 3 .

Goesniadhie, Kusnu. 2010. "Perspektif Moral Penegakan Hukum yang Baik.” Jurnal Hukum. vol. 17, no. 2 .

Manan, Bagir. 2009.“Beberapa Catatan tentang Penafsiran,” Varia Peradilan. vol. XXIV, no. 285.

Prayogo, R.Tony. 2016.“ Penerapan Asas Kepastian Hukum dalam Peraturan Mahkamah Agung Nomor 1 Tahun 2011 Tentang Hak Uji Materiil dan dalam Peraturan Mahkamah Konstitusi Nomor 06/PMK/2005 Tentang Pedoman Beracara dalam Pengujian Undang-Undang," Jurnal Legislasi Indonesia. vol. 13, no. 2.

Situngkir, Daniel Aditia, 2018. “Asas Legalitas dalam Hukum Pidana Nasional dan Hukum Pidana Internasional,” Jurnal Soumatera Law Review. vol. 1, no. 1.

Publikasi IImiah

Ismail, Fauzie Kamal. 2011. Kepastian Hukum Atas Akta Notaris yang Berkaitan dengan Pertanahan. Tesis, Universitas Indonesia.

\section{Artikel Online}

Southeast Asia Freedom of Expression Network. "Memahami dan Menyikapi Kekerasan Berbasis Gender Online Sebuah Panduan." Diakses pada 29 Maret. 2021. https://id.safenet.or.id/wp-content/uploads/2019/11/Panduan-KBGOv2.pdf.

“Arti Penafsiran Hukum Argumentum a Contrario," Hukum Online, diakses pada 4 April, 2021, https://www.hukumonline.com/klinik/detail/ulasan/lt58b4df16aec3d/arti-penafsiranhukum-iargumentum-a-contrario-i/.

“Catatan Kekerasan Terhadap Perempuan Tahun 2020," Komisi Nasional Perempuan dan Anak, diakses pada 01 April 2021, https://komnasperempuan.go.id/catatan-tahunan.

"Memahami dan Menyikapi Kekerasan Berbasis Gender Online Sebuah Panduan," Southeast Asia Freedom of Expression Network, diakses pada 29 Maret, 2021, https://id.safenet.or.id/wpcontent/uploads/2019/11/Panduan-KBGO-v2.pdf.

"Napi Cabuli Anak-Anak di Media Sosial, Polisi Beri Tips Ketapel" Kompas.com, diakses pada 03 April, 2021, https://nasional.kompas.com/read/2019/07/23/09503781/napi-cabuli-anakanak-di-media-sosial-polisi-beri-tips-ketapel?page=all.

"Penemuan Hukum Oleh Hakim (Rechtvinding)," Fakultas Hukum Universitas Tanjungpura, diakses pada 4 April, 2021, http://hukum.untan.ac.id/penemuan-hukum-oleh-hakimrechtvinding/.

Peraturan Perundang-Undangan

Undang-Undang Dasar Negara Republik Indonesia Tahun 1945.

Undang-Undang Republik Indonesia Nomor 44 Tahun 2008 tentang Pornografi.

Undang-Undang Republik Indonesia Nomor 48 Tahun 2009 tentang Kekuasaan Kehakiman. 
Undang-Undang Republik Indonesia Nomor 12 Tahun 2011 Tentang Pembentukan Peraturan Perundang-Undangan dan Undang-Undang Republik Indonesia Nomor 15 Tahun 2019 Tentang Perubahan Atas Undang-Undang Nomor 12 Tahun 2011 Tentang Pembentukan Peraturan Perundang-Undangan.

Undang-Undang Republik Indonesia Nomor 35 Tahun 2014 tentang Perlindungan Anak.

Undang-Undang Republik Indonesia Nomor 19 Tahun 2016 tentang Perubahan Atas UndangUndang Nomor 11 Tahun 2008 tentang Informasi dan Transaksi Elektronik. 